\title{
CIRCLES OF EXILE: A RESPONSE TO PROFESSOR FORBATH
}

\section{GARRETT EPPS $\dagger$}

There is a man who comes to consult me in my office at the University of Oregon, almost as a professional colleague might. We amicably discuss constitutional theory for a while, and then he goes away. $\mathrm{He}$ is a perfect gentleman and a fair debater when he is with me, but he is a member of a local militia, and a few years ago he was convicted of trespassing on land belonging to the United States Forest Service. ${ }^{1}$ When he came to trial, he explained that he was not trespassing, because the federal government had no right of ownership in the land; that the act of Congress that retained these lands upon Oregon's admission to the Union was unconstitutional; and, further, that the court had no power to try him, because Marbury v. Madison ${ }^{2}$ was wrongly decided. ${ }^{3}$

I mention this acquaintance only because Professor Forbath's essay $^{4}$ reminded me that the land of constitutional exile, like Dante's Hell, has different circles, the outermost of which harbors this man. (By "constitutional exile" I mean allegiance to a vision of the Constitution which has passed out of favor among those with power to in-

Copyright (C) 2001 by Garrett Epps.

$\dagger$ Associate Professor of Law, University of Oregon. This Essay is a response to William E. Forbath, The New Deal Constitution in Exile, 51 DuKE L.J. 165 (2001), presented at the Constitution in Exile conference hosted by the Program in Public Law at Duke University School of Law on October 5-7, 2000. I wish to thank Professor Christopher Schroeder, the Duke University School of Law Program in Public Law, and the editors of the Duke Law Journal for their work on the conference and for extending to me the chance to participate. Professor Forbath was most tolerant of my attaching these well-nigh irrelevant thoughts to his cogently argued paper. Participants at the conference, particularly Neal Devins, Neil Kinkopf, and Michael Kent Curtis, made very helpful comments. Chris Michali helped with research for this printed version. My colleagues Rennard Strickland, Ibrahim Gassama, and Keith Aoki are constant inspirations.

1. United States v. Medenbach, No. 96-30168, 1997 U.S. App. LEXIS 13256, at *12 (9th Cir. June 2, 1997).

2. 5 U.S. (1 Cranch) 137 (1803) (establishing the power of judicial review).

3. Medenbach, 1997 U.S. App. LEXIS 13256, at *12 (holding that Medenbach's "argument against the constitutionality of judicial review [was] meritless").

4. William E. Forbath, The New Deal Constitution in Exile, 51 DuKE L.J. 165 (2001). 
terpret the law-judges, politicians, lawyers, scholars, and others.) Some circles of exile are more comfortable-think tanks, law school faculties, and newspaper editorial boards. Governments in exile formed in these inner circles very quickly can find themselves in power, driving their foes into exile in turn. Other circles are drabber, colder, and more sparsely populated-public-access cable television talk shows and meetings of organizations like the Fully Instructed Jury Association or the many "tax-protester" organizations that will convince members, for a fee, that the income tax is unconstitutional. Those who live in these outer circles of exile are usually children of the constitutional diaspora, raised to yearn for an idealized constitutional homeland they never actually have seen.

Professor Forbath's eloquent summary of the tenets of New Deal constitutionalism and its concept of "social citizenship" describes a vision of society and of the Constitution that I always have found compelling. ${ }^{5}$ Professor Forbath lays out the forgotten history of the idea that citizenship, for the New Dealers, entailed more than passive obligations and negative liberties; it included the right to democratic control over economic institutions and to affirmative support from the state in realizing one's potential. ${ }^{6}$ For much of my adult life I looked forward to the restoration that would sweep social citizenship's adherents in from the inner circles of exile to their birthright of influence. Increasingly, however, I feel a kind of sympathy with my militia acquaintance. We do not occupy the same circle of exile, but for us both, the comforts of home seem more and more a distant memory. My children and I recite a family formula-something like, "If I forget thee, O Works Progress Administration, may my right hand lose its cunning"- - but I begin to despair that my children ever will see Jerusalem.

To understand why that is - and why, important as it is, Professor Forbath's vision does not necessarily prophesy a return-I suggest turning to the outermost corners of exile, to the last group of American reformers who were willing to declare that they stood not for the proper interpretation of the Constitution but for its repudiation: the radical wing of the abolitionist movement, the Garrisonian abolitionists. ${ }^{7}$ Studying abolitionism reveals that the real significance of dis-

\footnotetext{
5. Id. at 166 .

6. Id. at $176-78$.

7. Henry Mayer, All on Fire: William Lloyd Garrison and the Abolition of SLAVERY 327 (1998).
} 
putes over the Constitution's meaning often lies not in what the two sides disagree about, but in what they both take for granted. Abolitionists rejected the Constitution, to begin with, because it implicitly sanctioned slavery. ${ }^{8}$ But many radical abolitionists were also, at least at first, radical pacifists. They rejected the very idea of a nation-state on the grounds that its existence and maintenance required complicity in violence. ${ }^{9}$ The Constitution existed to form and protect a nation; the nation could not exist without the means and willingness to defend itself against other nations. Citizenship, in this analysis, meant accepting the ill-gotten benefits of this violent appropriation of the earth for the benefit of a few. Truly then, the Constitution was for the radical abolitionists "a covenant with death." ${ }^{, 10}$ I mention the Garrisonian abolitionists not because I also wish to repudiate the Constitution. Like most Americans (and of course like my acquaintance who believes that we took a wrong turn at Marbury), I am not only loyal to the Constitution, but also unshakably convinced that my vision of its meaning embodies the True Faith. The story of the abolitionists serves to remind us that our intense arguments about what the document includes can blind us to what-or to whom-it excludes.

It is, as Chief Justice Marshall famously wrote, "a constitution we are expounding," 11 and because of that, it is a nation we are constituting. Nations used to be defined geographically, with those inside the borders sharing the burdens and benefits of membership and those outside excluded. Today, however, nationhood has become independent of geography.

There exists now within our borders a substantial number of people who explicitly and by law possess fewer legal rights than everyone else. ${ }^{12}$ This is not an unprecedented state of affairs-though one can argue that slavery is the only analogous American precedent. The potential corrosive effects of this population's legal status on our notions of citizenship and equality are so huge that, like all transcendent social phenomena, they require an effort of will to see.

The population I am talking about consists of immigrants who have entered the country without legal permission or who have re-

\footnotetext{
8. Id.

9. This part of radical abolitionism is ably documented in NONVIOLENCE IN AMERICA: A DOCUMENTARY HistORY 14, 18 (Staughton Lynd \& Alice Lynd eds., rev. ed. 1995).

10. MAYER, supra note 7, at 313.

11. McCulloch v. Maryland, 17 U.S. (1 Wheat.) 316, 407 (1819).

12. See, e.g., 8 U.S.C. $\S \S 1226,1231$ (1994 \& Supp. V 1999) (establishing procedures for the apprehension, detention, and removal of aliens).
} 
mained after their permission has expired. Just as we forget the more extensive definition of citizenship that lies behind the New Deal, we also forget that the very concept of an "illegal alien" is a creature of the twentieth century and that it did not appear in law until the second half of the twentieth century. ${ }^{13}$

The term was relatively insignificant until $1965 .^{14}$ The Immigration and Naturalization Service was a kind of social service agency; now it is the largest law enforcement agency in the country. ${ }^{15}$ Illegal status used to be temporary; now it is often lifelong. (In 1993, thenCalifornia Governor Pete Wilson and the Federation for American Immigration Reform even proposed amending the Fourteenth Amendment to make illegal status hereditary. $)^{16}$ Increasingly, an illegal alien has, to coin a phrase, no rights that a citizen is bound to respect.

The existence of this population of legally subhuman workers renders problematic any attempt to define the rights of labor in a broader way. Employers who do not wish to pay prevailing wages can parcel out much of their work to illegal aliens, a population that is easy to control. Further, capital in the emerging world order can flow freely across borders. That means employers can thwart any attempt by the government to mandate the kinds of social benefits that underlay the New Deal concept of citizenship simply by threatening to

13. Fred Shapiro, librarian at Yale Law School and editor of the OXFORD DICTIONARY OF AMERICAN LEgAL QUOTATIONS (1993), dates the expression to 1947. E-mail from Fred Shapiro to Garrett Epps, Associate Professor of Law, University of Oregon (Sept. 21, 2001) (on file with the Duke Law Journal).

14. From 1942 until 1965, several million Mexicans were allowed to work as farmworkers in the United States. STEPHEN H. LEGOMSKY, IMMIGRATION AND REFUGEE LAW AND POLICY 954 (2d ed. 1997). This official program ended in 1965. Id. That same year, Congress revamped U.S. immigration law and abolished the previous exemption from numerical restrictions on immigration from other countries in the Western Hemisphere, with the exceptions of immediate relatives of American citizens and certain "special immigrants." Immigration and Nationality Act, Pub. L. No. 89-236, § 201(a), 79 Stat. 911, 911 (1965) (current version at 8 U.S.C. § 1151 (1994)); LEGOMSKY, supra, at 106. United States growers, who had become reliant on Mexican labor, responded by hiring illegal immigrants in place of the formerly legal Mexicans. Id. at 954 . In short, Congress gave birth to the illegal alien problem.

15. Garrett Epps, Immigration Service's Boot Is on Our Foot, OREgOnIAn (Portland, Or.), Dec. 19, 1999, at E1.

16. Vlae Kershner, Wilson's Plan to Curb Illegal Immigration, S.F. CHRon., Aug. 10, 1993, at A1. In addition, the George W. Bush administration has proposed amnesty for many undocumented immigrants of Mexican origin; this policy initiative immediately set off a fierce protest by other immigrant groups who have been excluded. Eric Schmitt, Bush Aides Weigh Legalizing Status of Mexicans in U.S., N.Y. TIMES, July 15, 2001, at A1; Eric Schmitt, Other Immigrants, Envying Mexicans, Demand a Break, Too, N.Y. TIMES, July 26, 2001, at A1. 
move the jobs abroad. In physical terms, immigration flow is nearly as free as capital flow. However, the flow of capital is open and legally protected; the flow of labor exists in a twilight world beneath law's notice and protection, depressing demands for a new definition of social citizenship. ${ }^{17}$ Reforms increasing the expectations of one country's residents for social support can be expected to attract immigration inflows while producing simultaneous capital outflows, which together reduce the amount of work for citizens and noncitizens alike. $^{18}$

Professor Forbath's essay details some of the effects of domestic legal inequality in the New Deal era, most particularly the Jim Crow system. ${ }^{19}$ But the New Deal idea of citizenship had an international component as well..$^{20}$ Roosevelt's "Four Freedoms" $" 21$ are the antecedents of today's increasingly formalized guarantees of international human rights. Many New Dealers understood freedom from hunger as a serious part of those freedoms. In fact, Henry Wallace once mused that the Second World War would not be won until "everybody in the world has the privilege of drinking a quart of milk a day." ${ }^{, 2}$ But the social citizenship aspect of international human rights and governance has been thwarted as surely as was the domestic aspect. Consider that the United Nations-created largely to embody New Deal notions of world citizenship-progressively has been weakened and increasingly is supplanted as a multilateral lawmaker by the World Trade Organization. ${ }^{23}$ Consider that human rights discourse, valuable as it is, more and more tends to ignore the social, or

17. G.M. Tamás, On Post-Fascism, Boston ReV., Summer 2000, at 42, 46.

18. Id.

19. Forbath, supra note 4, at 203-09.

20. Frank Donovan, Mr. Roosevelt's Four Freedoms: The Story Behind the UNITED NATIONS 23 (1966).

21. See id. at 25 (listing the "Four Freedoms" as freedom of speech and expression, freedom of worship, freedom from want, and freedom from fear).

22. Henry A. Wallace, Democracy Reborn 193 (1944).

23. See Daniel Tarullo, Norms and Institutions in Global Competition Policy, 94 AM. J. INT'L L. 478, 487 (2000):

Judged against its initial mandate to reduce tariffs and otherwise liberalize world trade, the [World Trade Organization] WTO (and its predecessor, the [General Agreement on Tariffs and Trade] GATT) has arguably been the most successful of the international organizations established at the close of World War II. This very success has attracted more and more issues into the WTO's orbit, including competition policy. 
positive, aspects of its founding documents $\mathrm{s}^{24}$ in order to concentrate on the purely legal or negative aspects. It is certainly exhilarating that more and more nations and tribunals recognize an international right not to be tortured. But the drafters of the Universal Declaration of Human Rights ${ }^{25}$ and the Covenants ${ }^{26}$ hoped that there also would be recognition of corresponding rights to food, shelter, education, and meaningful participation in the economy. The texts guaranteeing those rights seldom are cited these days.

Internationally, then, we, like the states of the Union in the era of Hammer $v$. Dagenhart, ${ }^{27}$ may find ourselves engaged in a race to the bottom. And the race covers more ground, because the emerging international order legalizes the mobility of capital without legalizing the mobility of labor. As the Hungarian philosopher G.M. Tamás wrote recently, this is not the first but the second regime of globalization. ${ }^{28}$ The first ended with the First World War; in that regime, workers were legally as free to move as were jobs. ${ }^{29}$ Now the migrations continue, but the laws embody a vision of citizenship that covers fewer and fewer of the people within a nation's borders. ${ }^{30}$ The result - the slow dismantling of the idea of universal citizenship and the inevitable reconnection of citizenship with a specific racial or ethnic background-Tamás labels "post-fascism." 31

The phenomenon is most visible in the new "democracies" of the former Soviet bloc, but we fight the same battle here. ${ }^{32}$ Until we create a constitutional doctrine more protective of the people who have come here as labor inputs, we cannot expect to make progress toward broader rights of participation and economic security than the fairly

24. These "positive" rights are most comprehensively set out in the International Covenant of Economic, Social, and Cultural Rights, adopted Dec. 16, 1966, 993 U.N.T.S. 3 (entered into force Jan. 3, 1976), which the United States has yet to ratify.

25. DEP'T OF PUb. INFO., U.N., YEARBOOK OF THE UNITED NATIONS SPECIAL EDITION U.N. FIFTIETH ANNIVERSARY, 1945-1995, at 303 (1995).

26. Id. at 306 (referencing the U.N. Covenants on Human Rights).

27. 247 U.S. 251, 269-77 (1918) (invalidating a federal law that prohibited the interstate shipment of goods manufactured by child labor).

28. Tamás, supra note 17 , at $42,45-46$.

29. Id. at 46.

30. $I d$.

31. Id. (characterizing the modern capitalist state as having adopted the post-fascist strategy through its revival of class politics).

32. See, e.g., Epps, supra note 15, at E1 (detailing how the policies of the Immigration and Naturalization Service resulted in a teenaged immigrant girl being jailed for seven months despite a grant of asylum). 
minimal consumer rights we enjoy today. And just as the problems of child labor and worker safety could not be cured by changing state constitutions, we also must recognize that the United States Constitution no longer (if it ever did) describes a largely self-contained polity, but that instead it is only one localized aspect of the broader struggle to establish a meaningful concept of world citizenship, of a world in which no one will feel the sting of exile and legal inequality. For this reason, one of the most important tasks facing constitutional scholars is that of defining more clearly-in ways that even, say, Supreme Court Justices can understand-the ways in which our domestic Constitution exists within a larger and increasingly more vital legal tradition of international institutions and legal norms.

It is in taking the first steps in that direction that we find ourselves marching in tandem with those early abolitionists. We must realize that today, one hundred and fifty years later, we still are wandering in the wilderness, not much closer to the promised land. 